\title{
Bone Marrow Transplantation Has a Significant Effect on Enzyme Levels and Storage of Glycosaminoglycans in Tissues and in Isolated Hepatocytes of Mucopolysaccharidosis Type VII Mice
}

\author{
B. J. H. M. POORTHUIS, A. E. ROMME, R. WILLEMSEN, AND G. WAGEMAKER
}

Department of Pediatrics, State University Leiden [B.J.H.M.P., A.E.R.], Department of Clinical Genetics [R.W.] and Hematology [G.W.], Erasmus University Rotterdam, The Netherlands

\section{ABSTRACT}

The effect of bone marrow transplantation (BMT) on enzyme and glycosaminoglycan levels of various tissues and isolated parenchymal cells of lethally irradiated gus ${ }^{\mathrm{mps}} /$ gus $^{\text {mps }}$ mice was studied. These mice have an inherited deficiency of the lysosomal enzyme $\beta$-glucuronidase with less than $1 \%$ of normal enzyme activity present in all tissues and represent a model of human mucopolysaccharidosis type VII. Tissues were evaluated $200 \mathrm{~d}$ after BMT and liver parenchymal cells $300 \mathrm{~d}$ after BMT. Normal levels of $\beta$-glucuronidase activities were present in spleen and peripheral blood leukocytes of gus ${ }^{\mathrm{mps}} / \mathrm{gus}^{\mathrm{mps}}$ mice that underwent transplantations. Intermediate activities were found in lung (73\%), kidney (4\%), liver $(10 \%)$, heart $(53 \%)$, muscle $(55 \%)$, brain $(6 \%)$, and liver parenchymal cells $(10 \%$ of normal controls). A concomitant decrease in activity of the secondarily increased enzyme $\beta$-hexosaminidase was observed. BMT also led to a substantial reduction in storage of glycosaminoglycans in lung (130 to 100\%), heart (350 to $106 \%$ ), kidney (439 to $217 \%$ ), brain (177 to $91 \%$ ), liver (613 to $125 \%$ ), and liver parenchymal cells (443 to $161 \%$ of normal controls). These findings were supported by elec- tron microscopy. A normalization of the storage process was seen in the visceral organs spleen and liver and in the histiocytes of the heart. The kidney showed variable improvement depending on the cell type. In the brain, a substantial improvement of neuronal storage was observed, but BMT apparently had no effect on storage in glial cells. The subcellular localization of $\beta$-glucuronidase was investigated in liver parenchymal cells of mice that underwent transplantation. Subcellular fractionation provided evidence for a lysosomal localization of $\beta$-glucuronidase, indicating that transfer of $\beta$-glucuronidase of donor origin to the lysosomal compartment of parenchymal cells might at least partly be responsible for the observed decrease in storage of glycosaminoglycans in these cells. (Pediatr Res 36: 187-193, 1994)
Abbreviations
BMT, bone marrow transplantation
MPS, mucopolysaccharidosis
GAG, glycosaminoglycan
EM, electron microscopy

The use of BMT as a form of enzyme replacement therapy for lysosomal storage diseases is based on the idea that bone marrow from a healthy donor and the short-lived cells derived from bone marrow provide a permanent source of the missing enzyme (1). Enzyme replacement may then take place by three possible mechanisms: replacement of enzyme-deficient cells by normal cells (2); enzyme transfer from normal bone marrowderived cells to deficient cells mediated by cell-cell contact $(3,4)$; and enzyme secretion by normal bone mar-

Received August 30, 1993; accepted February 24, 1994.

Correspondence: Ben J. H. M. Poorthuis, Ph.D., Department of Pediatrics, University Hospital, P.O. Box 9600, 2300) RC Leiden, The Netherlands.

Supported by Grant 28-1021-2 from "Praeventiefonds," The Netherlands. row-derived cells into the plasma and subsequent uptake in deficient cells by absorptive pinocytosis or receptormediated endocytosis (5). Once taken up by the cells, the normally functioning enzyme should reduce storage of specific metabolites inside the lysosome. Correction of the metabolic abnormality may result in clinical improvement. The first mechanism may be expected to be sufficient for clinical improvement only in those diseases that primarily affect the reticuloendothelial system such as Gaucher's disease type I. The possible importance of the second mechanism is difficult to evaluate at present, but the effect is obviously limited to those tissues that contain bone marrow-derived tissue macrophages, such as spleen, liver, and lung. As for the third mechanism, very 
little is known about the capacity of leukocytes and tissue macrophages to secrete lysosomal enzymes in vivo $(6,7)$, and the contribution of these cells to the total circulating pool of lysosomal enzymes is unknown. Similarly, it is not known whether these secreted enzymes are of a form that can be efficiently taken up by other cell types.

Yet another mechanism could potentially lead to decreased storage in the tissues (8). If a concentration gradient of storage product exists between tissues and plasma, continuous clearance of storage product from the plasma pool by cells of donor origin would be expected to lead to decreased tissue levels of storage product.

Studies in animal models are indispensable to gain insight into the displacement of host cells by donor cells and to study the uptake of lysosomal enzyme into cells not belonging to the reticuloendothelial system after BMT. A useful mouse model for MPS type VII was described some years ago (9). This mutant mouse, designated gus $^{\mathrm{mps}} /$ gus $^{\mathrm{mps}}$, has an inherited deficiency of the lysosomal enzyme $\beta$-glucuronidase and has clinical and pathologic abnormalities comparable to those found in human MPS type VII (10). Abnormal biochemical parameters associated with murine MPS VII include increased tissue GAG content and secondary elevations of several lysosomal enzymes including $\beta$-hexosaminidase. We have used this mouse model to study enzyme distribution and storage phenomena in tissues and isolated hepatocytes after long-term stable engraftment with syngeneic donor cells. The results of our biochemical and EM studies show that BMT leads to a substantial improvement in enzyme levels of $\beta$-glucuronidase and in storage of GAG in various tissues, including the brain, in the gus $^{\mathrm{mps}} /$ gus $^{\mathrm{mps}}$ mouse. Complete metabolic correction was observed in cells of hemopoietic origin, but the effect of BMT was not limited to these cells. Considerable improvement was also found in hepatocytes, neurons, and endothelial cells of the kidney. To test the hypothesis that $\beta$-glucuronidase originating from cells derived from donor hemopoietic cells actually reaches cells of nonhemopoietic origin, we performed studies with isolated liver parenchymal cells. The results of these experiments indicate transfer of $\beta$-glucuronidase of donor origin to the lysosomes of hepatocytes of the recipient gus $\mathrm{sps}^{\mathrm{mps}} / \mathrm{gus}^{\mathrm{mps}}$ mice.

\section{METHODS}

Animals. Breeding pairs carrying the mutant gus ${ }^{\mathrm{mps}}$ gene (C6.C-H-2 ${ }^{\text {bml }} /$ ByBir-gus ${ }^{\mathrm{mps}} /+$ mice) were made available to us by Dr. Edward $\mathrm{H}$. Birkenmeier (The Jackson Laboratory, Bar Harbor, ME). The mutation was transferred to a $\mathrm{C} 57 \mathrm{Bl} / \mathrm{Rij}$ background and the mutant strain was maintained by brother and sister matings using heterozygous mice. Affected (gus ${ }^{\mathrm{mps}} / \mathrm{gus}^{\mathrm{mps}}$ ), heterozygous, and normal mice were identified 3-5 d after birth by assaying the $\beta$-glucuronidase activity in clipped tails [sp act of gus ${ }^{\mathrm{mps}} /$ gus $^{\mathrm{mps}}$ mice, $0.4 \pm 0.2(n=30)$; heterozygotes, $27.4 \pm 4.2(n=140)$; and normal mice,
$57.1 \pm 9.1(n=180) \mathrm{nmol} / \mathrm{mg}$ protein/h. The mice were maintained under specific pathogen-free conditions.

$B M T$. Bone marrow cells were obtained by flushing the femors and tibias of normal $\mathrm{C} 57 \mathrm{Bl} / \mathrm{Rij}$ donor mice with $N$-2-hydroxyethylpiperazine- $N^{\prime}$-2-ethanesulfonic acidbuffered Hanks' balanced salt solution. One d after lethal irradiation $\left({ }^{137} \mathrm{Cs}\right.$ gamma rays, $\left.8.5 \mathrm{~Gy}\right), 10^{7}$ nucleated bone marrow cells were injected into the tail vein of $60-\mathrm{d}$-old gus $^{\mathrm{mps}} / \mathrm{gus}^{\mathrm{mps}}$ recipient mice. This procedure leads to stable and complete engraftment with donor cells (11).

Biochemical analyses. Mutant mice (gus ${ }^{\mathrm{mps}} / \mathrm{gus}^{\mathrm{mps}}$ ), mice that underwent transplantation $\left(\right.$ gus $^{\mathrm{mps}} / \mathrm{gus}^{\mathrm{mps}}+$ BMT), and normal mice were killed, and the various tissues were assayed for $\beta$-glucuronidase and $\beta$-hexosaminidase activities with fluorometric assays as described previously (11). Leukocytes were isolated after lysis of the red blood cells as described (12). Enzyme activities were determined in plasma, leukocytes, spleen, liver, lung, heart, muscle, kidney, and brain. GAG were quantitated with a dimethylene blue dye binding assay using a modification of the method of Farndale et al. (13). Compared with the original procedure, the time of papain digestion of tissues was extended from 1 to $4 \mathrm{~h}$. The incubation volume was $0.6 \mathrm{~mL}$ and the tissue protein concentration $20-30 \mathrm{mg} / \mathrm{mL}$. After papain digestion, 0.2 $\mathrm{mL}$ of chloroform were added and the incubation mixture was vigorously mixed and briefly centrifuged at $10000 \times$ $g$ to separate the phases. The GAG were determined in the clear supernatant. GAG content was expressed as $\mu \mathrm{g}$ of GAG per mg of protein. Protein was determined by the method of Lowry et al. (14).

Isolation of liver parenchymal cells. Liver parenchymal cells were isolated by collagenase treatment as described for rat liver by van Bezooyen et al. (15) and Seglen (16) with minor modifications to make the method suitable for mouse liver. The mice received an injection of anticoagulant [500 IU of Thromoboliquin (Organon Technica, Turnhout, Belgium) intraperitoneally] and were anesthetized with a mixture of three parts Aescoket (Aesculaap, Boxtel, The Netherlands), one part Rompun (Bayer, Leverkusen, Germany) $(2 \%)(0.01 \mathrm{~mL} / 10 \mathrm{~g}$ of body weight $)$. The liver was perfused through the portal vein with $\mathrm{Ca}^{2+}$-free perfusion medium (Hanks' balanced salt), $\mathrm{pH}$ 7.4 , saturated with $95 \%$ oxygen- $5 \%$ carbon dioxide for 15 min at $37^{\circ} \mathrm{C}$ with a flow rate of $1.2 \mathrm{~mL} / \mathrm{min}$ using a 26-gauge needle. An incision in the inferior vena cava was made to discharge the perfusion fluid. Subsequently, a perfusion was performed with medium containing $0.05 \%(\mathrm{wt} / \mathrm{vol})$ collagenase (type VIII; Sigma Chemical Co., St. Louis, MO) at a flow rate of $1.2 \mathrm{~mL} / \mathrm{min}$. The liver was removed, finely minced, and incubated for 5 min in medium containing in $0.05 \%(\mathrm{wt} / \mathrm{vol})$ collagenase. The cell suspension was sieved through a $90-\mu \mathrm{m}$ nylon filter and centrifuged for $1 \mathrm{~min}$ at $30 \times g$ (without brake) to obtain a parenchymal cell pellet. The cells were resuspended twice in $5 \mathrm{~mL}$ of buffer and centrifuged again for $1 \mathrm{~min}$ at $30 \times g$. The pellet consisted of liver parenchymal 
cells and was essentially free of nonparenchymal cells (>95\% pure) as judged by light microscopy after staining with hematoxylin and periodic acid-Schiff. The viability of these cells as measured with the trypan blue exclusion method was always $>75 \%$ and in most cases $>90 \%$.

Subcellular fractionation of liver parenchymal cells. Immediately after isolation, the parenchymal cells were homogenized in ice-cold $0.25 \mathrm{M}$ sucrose, $2 \mathrm{mM}$ EDTA, $10 \mathrm{mM}$ Tris- $\mathrm{HCl}, \mathrm{pH} 7.4(10 \% \mathrm{wt} / \mathrm{vol})$, using a PotterElvehjem homogenizer. The homogenate was centrifuged for $10 \mathrm{~min}$ at $750 \times \mathrm{g}$ at $4^{\circ} \mathrm{C}$. Of the resulting supernatant, $0.5 \mathrm{~mL}$ were mixed with $9 \mathrm{~mL}$ of $40 \%$ Percoll solution (Pharmacia, Uppsala, Sweden) and centrifuged for $20 \mathrm{~min}$ at $60000 \times \mathrm{g}$ at $4^{\circ} \mathrm{C}$ using a TFT 75.13 rotor (Kontron, Zurich, Switzerland).

Fractions of $0.5 \mathrm{~mL}$ were collected from the bottom of the tube and assayed for $\beta$-glucuronidase activity and the following marker enzymes: $\beta$-hexosaminidase (lysosomes), glucose-6-phosphatase (microsomes) (17), and glutamate dehydrogenase (mitochondria) (18).

Analysis of urinary GAG. Urine was collected for 4 consecutive d. After dilution with water to a creatinine value of $1.25 \mathrm{mM}$, the $\mathrm{pH}$ was adjusted to 4.5 and the GAG were precipitated with $0.1 \%$ cetyltrimethylammonium bromide. Electrophoresis of the GAG was carried out as described (19).

EM studies. Tissues were fixed in $0.1 \mathrm{M}$ phosphate

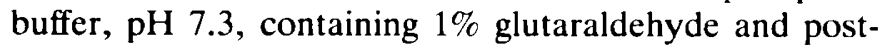
fixed in $0.1 \mathrm{M}$ phosphate buffer containing $1 \%$ osmium tetroxide. Standard procedures were used for epoxy resin embedding. Ultrathin sections were stained with uranyl acetate and lead citrate and examined in a Philips EM 400 electron microscope.

Statistical analysis. The results are expressed as mean \pm SD. The $t$ test was used for comparison between different groups.

\section{RESULTS}

$\beta$-Glucuronidase and $\beta$-hexosaminidase activities were measured in various tissues $200 \mathrm{~d}$ after BMT. The $\beta$-glucuronidase activity in leukocytes and spleen increased from almost undetectable to normal levels (Table 1), confirming that the BMT procedure led to stable and complete engraftment. The secondarily increased enzyme $\beta$-hexosaminidase reverted to normal levels in these tissues (Table 2). In agreement with these findings, EM investigation of the spleen indicated complete reversal of the storage process in this tissue (Fig. 1). Plasma $\beta$-glucuronidase activity rose to normal levels (Table 1 ), but the levels of $\beta$-hexosaminidase-although lower than in the untreated animals-remained consistently above normal (Table 2). Significant effects of BMT on $\beta$-glucuronidase activity were observed in lung (73\%), heart (53\%), and muscle (55\% of normal controls) (Table 1). Smaller effects were measured in kidney $(4 \%)$, brain $(6 \%)$, and liver (10\% of normal controls) (Table 1). Concomitant with the increase in $\beta$-glucuronidase activity, a
Table 1. Effect of BMT on $\beta$-glucuronidase activity $(\mathrm{nmol} / \mathrm{mg} / \mathrm{h})$ in $\mathrm{gus}^{\mathrm{mpss}} / \mathrm{gus}^{\mathrm{mps}}$ mice $^{*}$

\begin{tabular}{lccc}
\hline & $\begin{array}{c}\text { Normal } \\
(n=5)\end{array}$ & $\begin{array}{c}\text { gus }^{\mathrm{mps}}\left(\text { gus }^{\mathrm{mps}}\right. \\
(n=3)\end{array}$ & $\begin{array}{c}\text { gus }^{\mathrm{mps}} / \mathrm{gus}^{\mathrm{mps}} \\
(n=5)\end{array}$ \\
\hline Plasma & $9.4 \pm 2.1$ & $0.6 \pm 0.2$ & $12.8 \pm 4.2+\ddagger$ \\
Leukocytes & $89 \pm 8$ & $0.5 \pm 0.3$ & $90 \pm 16+\ddagger$ \\
Spleen & $169 \pm 17$ & $0.3 \pm 0.06$ & $165 \pm 19+\ddagger$ \\
Lung & $71 \pm 6$ & $0.18 \pm 0.05$ & $52 \pm 11+\S$ \\
Heart & $4.6 \pm 0.6$ & $0.15 \pm 0.09$ & $2.5 \pm 0.2+\S$ \\
Muscle & $2.2 \pm 0.7$ & $0.14 \pm 0.09$ & $1.2 \pm 0.7|| 9$ \\
Kidney & $122 \pm 27$ & $0.06 \pm 0.03$ & $5.0 \pm 1.1+\S$ \\
Brain & $10.5 \pm 1.3$ & $0.05 \pm 0.04$ & $0.60 \pm 0.17+\S$ \\
Liver & $199 \pm 25$ & $0.2 \pm 0.1$ & $20 \pm 5+\S$ \\
\hline
\end{tabular}

* $\beta$-Glucuronidase activity was determined in gus ${ }^{\mathrm{mps}} /$ gus $^{\mathrm{mps}}$ mice 200 d after BMT. Age-matched normal controls were used. The gus ${ }^{\mathrm{mps}} /$ gus $^{\mathrm{mps}}$ mice were $150 \mathrm{~d}$ old. Values are mean \pm SD.

$\dagger p<0.01$ is gus $^{\mathrm{mps}} /$ gus $^{\mathrm{mps}}$.

$\ddagger$ Not significant $i$ 's normal control.

$\S p<0.01$ is normal control.

$\| p<0.05$ i's gus ${ }^{\mathrm{mps}} / \mathrm{gus}^{\mathrm{mps}}$.

If $p<0.05$ is normal control.

significant reduction in $\beta$-hexosaminidase activity from several times the normal level to levels slightly above normal was observed in all tissues (Table 2). These results partially confirm and extend those of previous studies in the gus ${ }^{\mathrm{mps}} / \mathrm{gus}^{\mathrm{mps}}$ mouse (20) and in the $\mathrm{C} 3 \mathrm{H}$ and $\mathrm{B} 6 \mathrm{H}$ mouse, other models of low $\beta$-glucuronidase activity $(11,21)$.

The effect of BMT on the storage process was further investigated by measuring the levels of GAG in lung, heart, kidney, brain, and liver. Normalization or near normalization of the GAG levels was found in lung, heart, brain, and liver, whereas the GAG levels in kidney decreased from $540 \%$ to $220 \%$ of normal (Table 3). In support of the quantitative data, EM studies of the heart show a significant effect of BMT on the storage in tissue histiocytes (Fig. 2). In brain, a significant effect on storage in neuronal cells of the cerebral cortex was observed, whereas the glial cells still seemed to be affected after

Table 2. Effect of BMT on $\beta$-hexosaminidase activity (nmol/mg/h) in gus $s^{\text {mps }} /$ gus $^{\text {mps }}$ mice*

\begin{tabular}{|c|c|c|c|}
\hline & $\begin{array}{l}\text { Normal } \\
(n=5)\end{array}$ & $\begin{array}{c}\text { gus }^{\mathrm{mps}} / \text { gus }^{\mathrm{mps}} \\
(n=3)\end{array}$ & $\begin{array}{c}\text { gus }^{\text {mps }} / \text { gus }^{\mathrm{mps}} \\
+\mathrm{BMT} \\
(n=5)\end{array}$ \\
\hline Plasma & $2345 \pm 280$ & $7998 \pm 69$ & $4300 \pm 738+\div$ \\
\hline Leukocytes & $1284 \pm 139$ & $1513 \pm 186$ & $1281 \pm 273 \S \|$ \\
\hline Spleen & $3230 \pm 406$ & $14424 \pm 2982$ & $3417 \pm 353 \|$ \\
\hline Lung & $752 \pm 52$ & $5195 \pm 170$ & $1135 \pm 226 \dagger^{* *}$ \\
\hline Heart & $141 \pm 13$ & $2315 \pm 462$ & $188 \pm 9+\ddagger$ \\
\hline Muscle & $59 \pm 5$ & $591 \pm 334$ & $71 \pm 15 \|$ \\
\hline Kidney & $1391 \pm 175$ & $5922 \pm 608$ & $1941 \pm 61 \dagger \ddagger$ \\
\hline Brain & $1291 \pm 81$ & $7183 \pm 1284$ & $2339 \pm 219 \ddagger$ \\
\hline Liver & $699 \pm 333$ & $7313 \pm 1912$ & $904 \pm 135 \| 9$ \\
\hline
\end{tabular}

* Values are mean $\pm \mathrm{SD}$

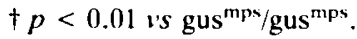

$\ddagger p<0.01$ vs normal control.

$\S$ Not significant vs gus ${ }^{\mathrm{mps}} / \mathrm{gus}$ mps.

$\|$ Not significant $v$ s normal control.

9 $p<0.05$ is gus gmps/gus $^{\mathrm{mps} \text {. }}$

${ }^{* *} p<0.05$ vs normal control. 

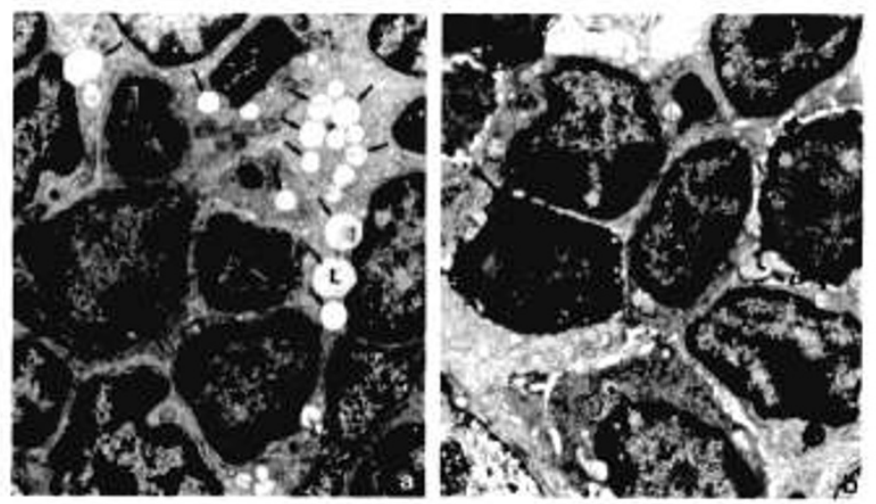

Figure 1. Effect of BMT on lysosomal storage in the spieen. The electron micrograph of the spleen of 150 -d-old gus ${ }^{\mathrm{mps}} / \mathrm{gus}^{\mathrm{mps}}$ mice shows extensive vacuolation ( $a$, arrows). Original magnification $\times 6750$. At $200 \mathrm{~d}$ after BMT, no lysosomal storage phenomena were observed in the spleen of animals that underwent transplantation $(b)$. Original magnification $\times 7500 . N$, nucleus; $L$, lysosome.

BMT (Fig. 3). In liver, a completely normal appearance without vacuolation was seen in the Kupffer cells as well as in the parenchymal cells after BMT (Fig. 4). In the kidney, the correction observed by EM was partial and varied with the cell type. A significant improvement to virtual normalization was seen in many endothelial cells lining the capillaries and the glomeruli (results not shown). The podocytes still showed extensive storage after BMT, although the content of the storage vacuoles in these cells after BMT differed from those of gus ${ }^{\mathrm{mps}}$ / gus $^{\mathrm{mps}}$ mice that did not undergo transplantation (Fig. 5). Also, the tubular epithelial cells showed extensive storage in mice that did and mice that did not undergo transplantation, with more electron dense material present after BMT (results not shown). The effect of BMT on mesangial cells could not be evaluated with certainty. The urinary excretion of GAG completely normalized after BMT (Fig. 6).

To study the effect of BMT on cells that are not of hemopoietic origin, the levels of $\beta$-glucuronidase, $\beta$-hexosaminidase, and GAG were measured in isolated hepatocytes. After BMT, $\beta$-glucuronidase activity was found to be present in these cells at about $10 \%$ of normal levels

Table 3. GAG content ( $\mu \mathrm{g} / \mathrm{mg}$ protein) of normal mice, gus $^{m p s} / g^{\prime m p s}$ mice, and gus ${ }^{m p s} / g u s^{m p s}$ mice that underwent transplantation*

\begin{tabular}{lccc}
\hline & $\begin{array}{c}\text { Normal } \\
(n=5)\end{array}$ & $\begin{array}{c}\text { gus }^{\mathrm{mps}} / \text { gus }^{\mathrm{mps}} \\
(n=3)\end{array}$ & $\begin{array}{c}\text { gus }^{\text {mps}} / \text { gus }^{\mathrm{mps}} \\
+\mathrm{BMT} \\
(n=4)\end{array}$ \\
\hline Lung & $6.6 \pm 1.8$ & $8.6 \pm 1.6$ & $7.2 \pm 2.0 \dagger \ddagger$ \\
Heart & $0.49 \pm 0.07$ & $1.72 \pm 0.14$ & $0.52 \pm 0.10 \neq \$$ \\
Kidney & $3.6 \pm 0.4$ & $19.4 \pm 5.5$ & $7.8 \pm 2.3 \S \|$ \\
Brain & $2.2 \pm 0.4$ & $3.9 \pm 0.6$ & $2.0 \pm 0.3 \neq \$$ \\
Liver & $2.4 \pm 0.2$ & $14.7 \pm 0.1$ & $3.0 \pm 0.5 \ddagger \S$ \\
\hline
\end{tabular}

* Values are mean \pm SD.

$\dagger$ Not significant i's gus ${ }^{\mathrm{mp} /} / \mathrm{gus}^{\mathrm{mp}}$.

$¥$ Not significant $v$ 's normal control.

$\S p<0.01$ v's gus $^{\text {mps }} /$ gus $^{\text {mips. }}$.

$\| p<0.01$ is normal control.

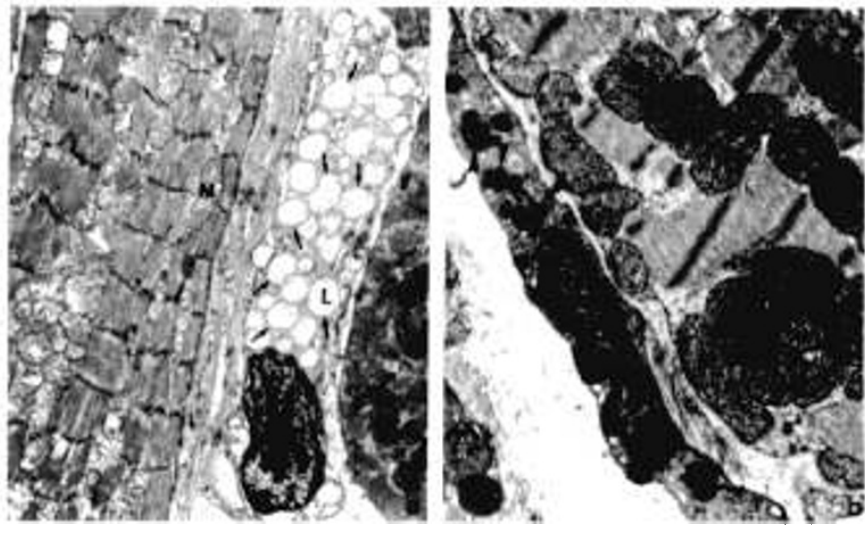

Figure 2. Effect of BMT on lysosomal storage in heart tissue. The electron micrograph of heart muscle of $150-\mathrm{d}$-old gus $\mathrm{mps}^{\mathrm{mpus}} \mathrm{gms}^{\mathrm{mps}}$ mice shows extensive vacuolation in the histiocytes but no involvement of the muscle cells $(a$, arron's). Original magnification $\times 6000$. At $200 \mathrm{~d}$ after BMT, the histiocytes no longer show abnormal storage in the animals that underwent transplantation ( $b$, arrowheads). Original magnification $\times 12000$.

(Table 4). A reduction of $\beta$-hexosaminidase levels in hepatocytes was observed, but the activity remained significantly increased above normal. The levels of GAG were reduced after BMT to levels slightly above normal.

The subcellular localization of $\beta$-glucuronidase in hepatocytes was investigated by fractionation of a postnuclear supernatant on self-generating Percoll gradients.
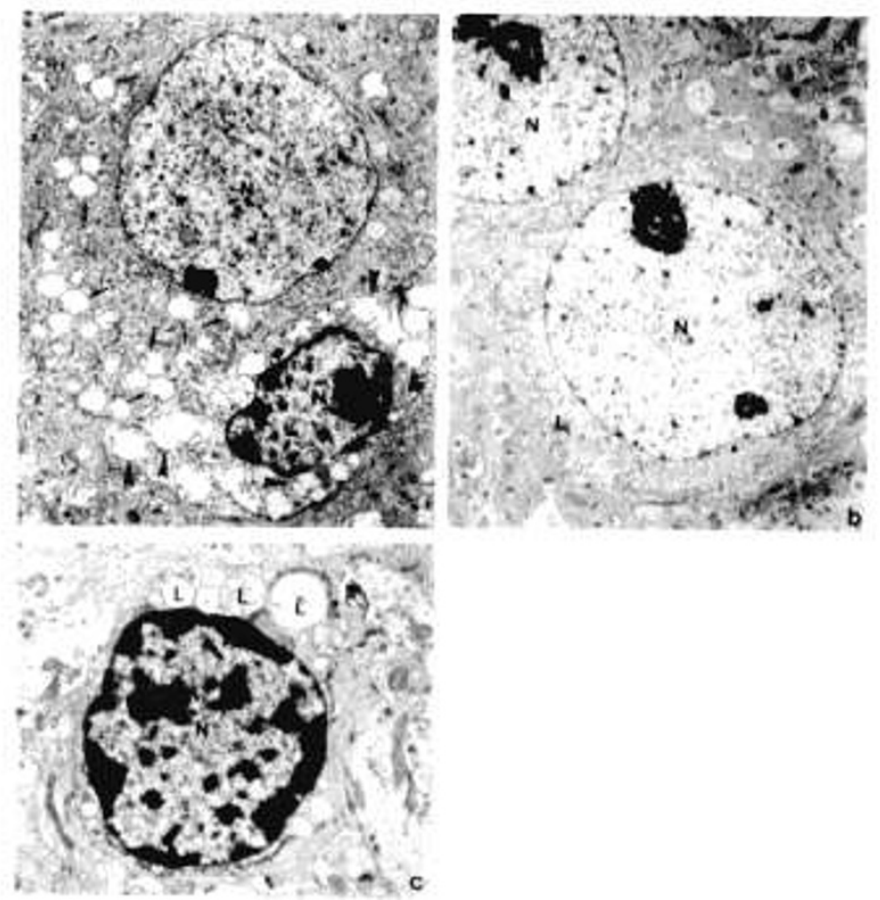

Figure 3. Effect of BMT on lysosomal storage in brain tissue. Both the neuronal and glial cells of the cerebral cortex of 150 -d-old gus ${ }^{\text {mps }} / \mathrm{gus}^{\mathrm{mps}}$ mice show extensive storage phenomena upon electron microscopic examination $[a$, lysosomal storage in neurons (arrows) or in glial cells (arrowheads)]. Original magnification $\times 5750$. After BMT, an improvement was observed in the neuronal cells $(b$, original magnification $\times 80(0))$. The degree of storage in the glial cells still seemed to be extensive after $\mathrm{BMT}(c$, original magnification $\times 12(000) . N$, nucleus; $L$, lysosome). 


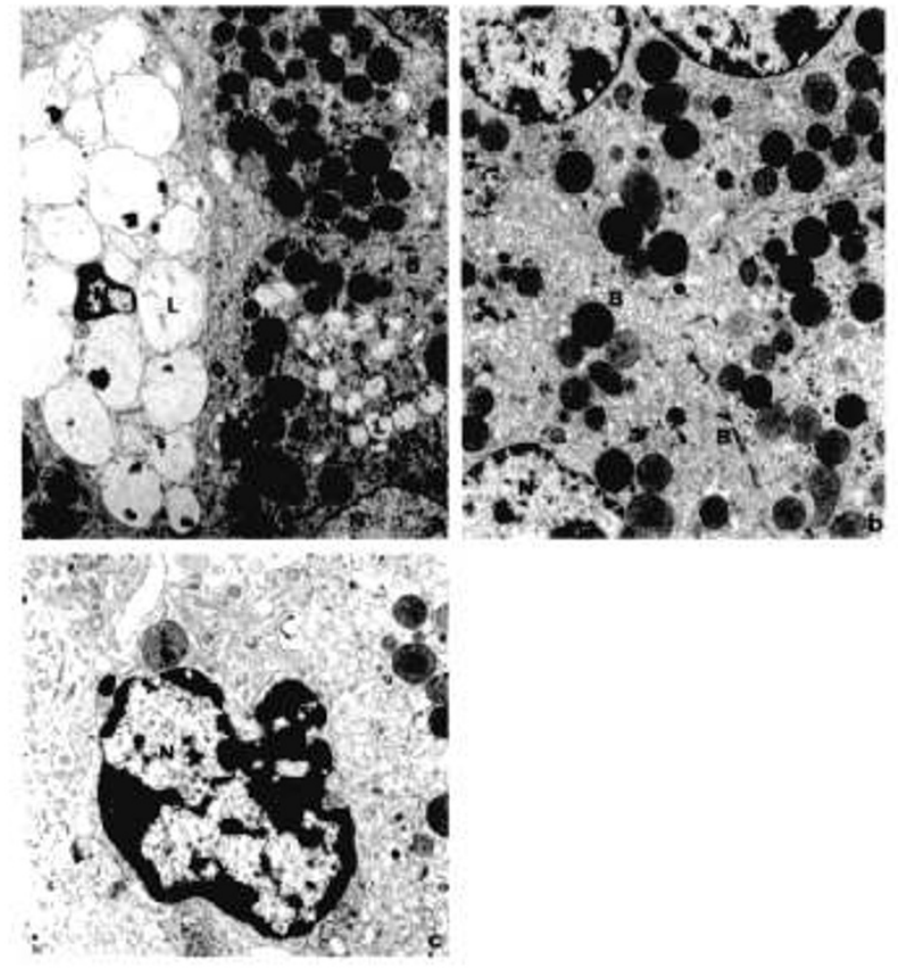

Figure 4. Effect of BMT on lysosomal storage in liver tissue. The electron micrograph of the liver of 150 -d-old gus $^{\mathrm{mps}} /$ gus $^{\mathrm{mps}}$ mice shows extensive storage in the very large lysosomes of the Kupffer cells and the smaller lysosomes of the hepatocytes $(a$, arrows $)$. Original magnification $\times 5500$. At $200 \mathrm{~d}$ after BMT, the appearance of both the hepatocytes $(b$, original magnification $\times 6750)$ and the Kupffer cells $(c$, original magnification $\times 8250$ ) was completely normal. $N$, nucleus; $L$, lysosome; $M$, mitochondrion; $B$, bile canaliculi.

Figure 7 shows the results of such experiments. Figure $7 a$ shows the distribution of $\beta$-glucuronidase and hexosaminidase in normal liver. Hepatocytes show a bimodal distribution of $\beta$-glucuronidase activity, in agreement with its lysosomal and microsomal localization (22). The activity cosedimented with the lysosomal marker hexosaminidase and with the microsomal marker glucose-6phosphatase (fractions 14 and 15). A similar pattern was found after BMT in a normal mouse, showing that BMT

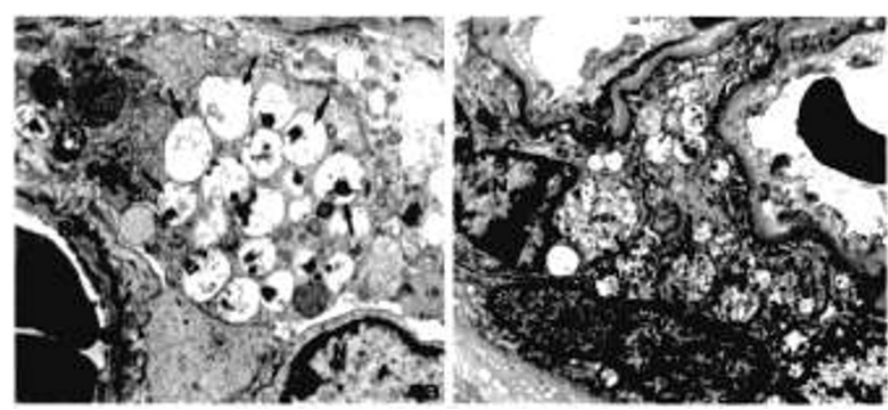

Figure 5. Effect of BMT on lysosomal storage in kidney. Extensive vacuolation of the podocytes was observed in gus ${ }^{\mathrm{mps}} / \mathrm{gus}^{\mathrm{mps}}$ mice. The lysosomes contained mostly electron-lucid storage material ( $a$, original magnification $\times 9250$ ). After BMT, the vacuolation was still extensive but the lysosome contained more electron-dense and membranous material than before BMT $(b$, arrows $)$. $E$, erythrocyte; $B M$, glomerular basement membrane: $N$, nucleus.

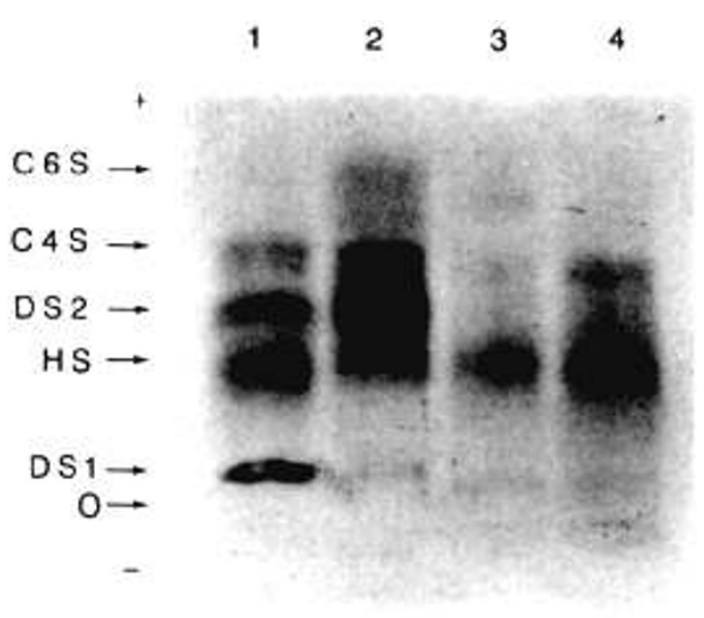

Figure 6. Electropherogram of GAG isolated from urine of a 150-d-old gus $^{\mathrm{mps}} /$ gus $^{\mathrm{mps}}$ mouse (lane 2), a gus ${ }^{\mathrm{mps}} /$ gus $^{\mathrm{mps}}$ mouse $200 \mathrm{~d}$ after BMT (lane 3), and a normal mouse (lane 4). Urine from a patient with Hunter's disease was used as a reference (lane 1 ). C6S, chondroitin-6sulfate; $C 4 S$, chondroitin-4-sulfate; $D S l$ and $D S 2$, dermatan sulfate; $H S$, heparan sulfate; $O$, origin; + , anode; - cathode.

per se did not affect the distribution of these enzymes in normal tissues (Fig. $7 b$ ). Figure $7 c$ shows a shift of the lysosomal marker enzyme hexosaminidase in hepatocytes of affected gus $^{\mathrm{mps}} / \mathrm{gus}^{\mathrm{mps}}$ mice toward fractions of lower density. Apparently, storage lysosomes have a significantly lower density than normal lysosomes. $\beta$-Glucuronidase was completely absent. After BMT, the distribution of the lysosomal marker hexosaminidase showed a normal pattern (Fig. $7 d$ ). This indicates a reversal of the storage process and confirms the EM findings presented in Figure 4 . The activity of $\beta$-glucuronidase closely followed the pattern of hexosaminidase, indicating its lysosomal localization (Fig. $7 d$ ).

\section{DISCUSSION}

The normal values of $\beta$-glucuronidase in peripheral blood leukocytes and spleen, the normalization of the secondarily increased enzyme $\beta$-hexosaminidase in these tissues, and the complete disappearance of the storage vacuoles in spleen and Kupffer cells as shown by our EM findings confirm the importance of cell replacement in the process of metabolic correction by BMT in tissues that are rich in cells of hemopoietic origin. The increase of

Table 4. Enzyme levels (nmol/mg/h) and GAG content $(\mu \mathrm{g} / \mathrm{mg}$ protein) of hepatocytes of normal mice, gus ${ }^{m p s} / g u s^{m p s}$ mice, and gus ${ }^{m p s} / g u s^{m p s}$ mice that underwent transplantation*

\begin{tabular}{lccc}
\hline & $\begin{array}{c}\text { Normal } \\
(n=5)\end{array}$ & $\begin{array}{c}\text { gus }^{\text {mps}}\left(\text { gus }^{\mathrm{mps}}\right. \\
(n=3)\end{array}$ & $\begin{array}{c}\text { gus }^{\text {mps}} / \text { gus }^{\text {mps }} \\
+ \text { BMT } \\
(n=5)\end{array}$ \\
\hline B-Glucuronidase & $187 \pm 23$ & $0.4 \pm 0.3$ & $22 \pm 7 \dagger$ \\
B-Hexosaminidase & $505 \pm 217$ & $2606 \pm 507$ & $1143 \pm 334 \dagger$ \\
GAG content & $2.3 \pm 0.1$ & $10.2 \pm 1.2$ & $3.7 \pm 0.2 \dagger$ \\
\hline
\end{tabular}

* Animals that underwent transplantation were evaluated $300 \mathrm{~d}$ after BMT and age-matched control animals were used. Gus ${ }^{\text {mps }} /$ gus $^{\text {mps }}$ mice were $150 \mathrm{~d}$ old.

$\dagger p<0.01$ vs gus $^{\mathrm{mps}} / \mathrm{gus}^{\mathrm{mps}}$ and is normal control. 

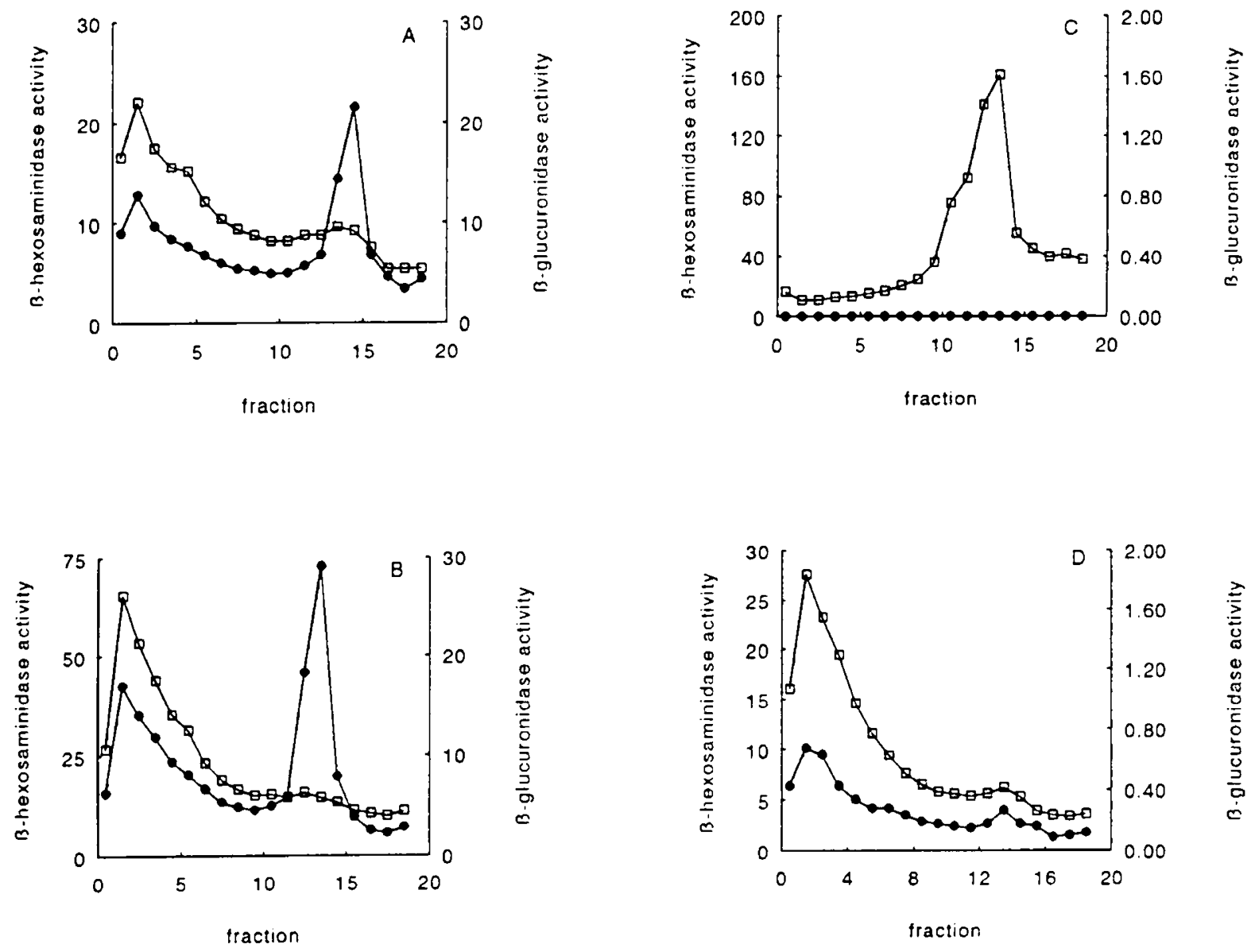

Figure 7. Fractionation of postnuclear supernatant of hepatocytes of normal mice $(A)$, normal mice 30() $\mathrm{d}$ after $\mathrm{BMT}(B)$, 150 -d-old gus ${ }^{\mathrm{mps}} /$ gus ${ }^{\mathrm{mps}}$ mice $(C)$, and gus ${ }^{\mathrm{mps}} / \mathrm{gus}^{\mathrm{mps}}$ mice $300 \mathrm{~d}$ after BMT $(D)$. Fractions $(2-20$ are in order of decreasing density. Enzyme activities are expressed as $\mathrm{nmol} / \mathrm{h} / \mathrm{mL}$ fraction, normalized per $\mathrm{mg}$ of protein applied to the gradient. Results are representative examples of duplicate experiments. $\square$. $\beta$-hexosaminidase activity; $\beta, \beta$-glucuronidase activity.

$\beta$-glucuronidase activity in lung and the reduction of $\beta$-hexosaminidase activity can also be at least partly explained by the presence of macrophages of hemopoietic origin in this tissue (23). However, the effect of BMT was not limited to cells of the reticuloendothelial system. Also neurons, endothelial cells of the kidney, and hepatocytes showed considerable improvement after BMT. Two mechanisms that could possibly have contributed to the observed improvement in these cells are uptake by the cells of enzyme originating from bone marrow-derived cells of donor origin and continuous clearance of the GAG from the plasma pool by cells derived from the normal bone marrow.

So far, direct evidence for enzyme replacement in cell types not belonging to the hemopoietic cell lineage has not been obtained. Our studies on isolated hepatocytes show that $\beta$-glucuronidase activity is present in the lysosomes of these cells in long-term stable engrafted gus $^{\mathrm{mps}} / \mathrm{gus}^{\mathrm{mps}}$ mice. This enzyme activity may have contributed to the normalization of lysosomal appearance observed by EM examination. The fact that $\beta$-hexosaminidase and GAG levels were still above control levels indicates that, despite the normal appearance of lysosomes, the storage process had not completely been reversed $300 \mathrm{~d}$ after BMT.
The mechanism by which $\beta$-glucuronidase actually reaches the lysosomal compartment of the hepatocytes is not clear. One possible explanation is that $\beta$-glucuronidase originating from cells of hemopoietic origin is shed into the circulation. The increase in circulating $\beta$-glucuronidase activity in plasma after BMT suggests that this does indeed occur. Subsequently, the enzyme may be taken up by hepatocytes, possibly by a receptormediated uptake mechanism, resulting in an increased activity of $\beta$-glucuronidase in the lysosomes of these cells. Alternatively, $\beta$-glucuronidase could be transferred from donor-derived Kupffer cells directly to neighboring hepatocytes. Earlier studies on tetraparental mice have provided evidence for intercellular transfer of $\beta$-glucuronidase in vivo in several tissues $(24,25)$. In addition, transfer of $\beta$-glucuronidase from competent to deficient cells has been shown to occur in vitro between lymphocytes and fibroblasts in a mannose-6-phosphate receptorindependent way $(3,4)$. It is as yet impossible to distinguish between these two possible mechanisms, and it is conceivable that both mechanisms have contributed to the observed rise in $\beta$-glucuronidase activity in hepatocytes. A similar uptake mechanism could also be active in other cell types. 
The normalization of the excretion of GAG in urine could be taken as an indication that circulating GAG are metabolized by cells of donor origin in the transplanted gus $^{\mathrm{mps}} /$ gus $^{\mathrm{mps}}$ mouse. This should lead to a lower total body burden of stored GAG, which may in turn contribute to improvement of the storage process that we have observed in cells of nonhemopoietic origin in liver, kidney, and brain.

In conclusion, we have shown that significant biochemical improvement in gus ${ }^{\mathrm{mps}} /$ gus $^{\mathrm{mps}}$ mice is obtained by BMT under the condition of complete and stable engraftment. Both cell replacement and enzyme transfer are likely to have contributed to the observed effects. However, the effect of BMT was partial despite optimal conditions of long-term engraftment. It seems reasonable to expect a similar partial effect of BMT in human MPS VII. This may be sufficient to justify BMT in MPS VII patients with minimal CNS involvement. Allogeneic BMT in human patients requires a compatible donor, and the procedure is not without risk. Gene therapy by retrovirus-mediated gene transfer to a patient's own bone marrow stem cells would be an alternative. However, unless infected cells have an unexpected advantage (e.g. overexpressing the missing enzyme), this form of therapy is expected to be less efficient than BMT, inasmuch as only a fraction of the stem cells will be infected. This was recently shown in gene transfer experiments in the gus $^{\mathrm{mps}} /$ gus $^{\mathrm{mps}}$ mouse (26). This calls for cautious optimism with respect to the application of these forms of therapy for MPS storage diseases and suggests that alternative forms of therapy such as enzyme therapy should be vigorously pursued.

Acknowledgments. The authors thank Dr. E. H. Birkenmeier, The Jackson Laboratory, Bar Harbor, Maine, for providing breeding pairs of gus ${ }^{\mathrm{mps}} /$ gus $^{\mathrm{mps}}$ mice; Dr. M. Veselic, Department of Clinical Cytology, Leiden, for her help in determining the purity of the isolated hepatocytes; and Dr. J. E. M. Groener for critically reading the manuscript.

\section{REFERENCES}

1. Hobbs JR, Hugh-Jones K. Barrett AJ, Chambers D, Henry K, James DCO, Lucas CF. Rogers TR, Benson PF, Tansley LR, Patrick AD, Mossman J, Young EP 1981 Reversal of clinical features of Hurler's disease and bicchemical improvement after treatment by bone marrow transplantation. Lancet 2:7(x)-712

2. Wagemaker G 1985 Hemopoietic cell differentiation. In: van Bekkum DW, Lowenberg B (eds) Bone Marrow Transplantation, Biological Mechanisms and Clinical Practice. Dekker Inc, New York, pp 1-72
3. Olsen 1, Dean MF. Harris G. Muir H 1981 Direct transfer of a lysosomal enzyme from lymphoid cells to deficient fibroblasts. Nature 291:241-247

4. Dean MF, Cooper JA. Stahl P 1988 (ell contact and direct transfer hetween co-cultured microphages and fihroblasts. J Leukoc Biol 43:539-546

5. Stahl P, Schwartz AL 1986 Receptor-mediated endocytosis. J Clin Invest 77:65.57-062

6. Imort M, Zühlsdorf M, Feige U, Hasilik A, von Figura K 1983 Biosynthesis and transport of lysosomal enzymes in human monocytes and macrophages. Biochem J 214:671-678

7. Zühlsdorf M, Imort M, Hasilik A, von Figura K 1983 Molecular forms of B-hexosaminidase and cathepsin $D$ in serum and urine of healthy subjects and patients with elevated activity of lysosomal enzymes. Biochem $\mathrm{J}$ 213:73,3-740

8. Barranger JA 1984 Marrow transplantation in genetic disease. $N$ Engl J Med 311:1629-16.31

9. Birkenmeier EH, Davisson MT, Beamer WG, Ganschow RE, Vogler CA Gwynn B, Lyford KA. Maltais L.M. Wawrzyniak CJ 1989 Murine mucopolysaccharidosis type VII: characterization of a mouse with $\beta$-glucuronidase deficiency. J Clin Invest 83:1258-1266

10. Vogler C, Birkenmeier EH, Sly WS, Levy B, Pegors C, Kyle JW, Beamer WG 1989 A murine model of mucopolysaccharidosis VII: gross and microscopic findings in $\beta$-glucuronidase-deficient mice. Am J Pathol 136:207-217

11. Hoogerbrugge PM. Poorthuis BJHM. Mulder AH. Wagemaker G, Dooren LJ, Vossen JMJJ, van Bekkum DW 1987 Correction of lysosomal enzyme deficiency in various organs of $\beta$-glucuronidase-deficient mice by allogeneic bone marrow transplantation. Transplantation 43:6(0)9-614

12. Roos D, Loos JA 1970) Changes in the carbohydrate metabolism of mitogenically stimulated human peripheral lymphocytes. Biochim Biophys Acta 222:565-582

13. Farndale RW, Sayers CA. Barrett AJ 1982 A direct spectrophotometric microassay for sulfated glycosaminoglycans in cartilage cultures. Connect Tissue Res 9:247-248

14. Lowry OH, Rosebrough NJ, Farr AL. Randall RJ 1951 Protein measurement with the Folin phenol reagent. J Biol Chem 193:265-275

15. van Bezooyen CFA, Grell T, Knook DL 1977 The effect of age on protein synthesis by isolated liver parenchymal cells. Mech Ageing Dev 6:243$3(1) 4$

16. Seglen PO 1976 Preparation of isolated rat liver cells. Methods Cell Biol 13:29-83

17. Narisawa K. Otomo H. Igarashi Y, Arai N, Otake M, Tada K. Kuzuya T 198.3 Glycogen storage disease type 1B: microsomal glucose-6-phosphatase system in two patients with different clinical findings. Pediatr Res 17:545549

18. Wanders RJA, van Roermund CWT, de Vries CT, van den Bosch $H$, Schrakamp G, Tager JM, Schram AW, Schutgens RBH 1986 Peroxisomal $\beta$-oxidation of palmitoyl-COA in human liver homogenates and its deficiency in the cerebro-hepato-renal (Zellweger) syndrome. Clin Chim Acti 159:1-10

19. Hopwood JJ, Harrison JR 1982 High-resolution electrophoresis in urinary glycosaminoglycans: an improved screening test for the mucopolysaccharidoses. Anal Biochem 119:120-127

20. Birkenmejer EH, Barker JE, Vogler C, Kyle JW, Sly WS, Gwynn B, Levy B. Pegors C 1991 Increased life span and correction of metabolic defects in murine mucopolysaccharidosis type VII after syngeneic bone marrow transplantation. Blood 78:3081-3.3092

21. Bou-Gharios G, Adams G, Pace P. Olsen I 1992 Long term effects of bone marrow transplantation on lysosomal enzyme replacement in mice. J Inherit Metab Dis 15:899-910

22. Paigen K 1979 Acid hydrolases as models of genetic control. Ann Rev Gene 13: $+17-466$

23. Thomas ED, Rambey RE, Sale JE. Sparks RS, Golde DW 1976 Direct evidence for a bone marrow origin of the alveolar macrophages in man. Science 192:1016-1018

24. Feder $N$ 1976 Solitary eell and enzyme exchange in tetraparental mice. Nature 263:67-68

25. Herrup K. Mullen RJ 1979 Intercellular transfer of $\beta$-glucuronidase in chi meric mice. J (ell Sci 4):21-31

26. Wolfe JH, Sands MS, Barker JA, Gwynn B, Rowe L.B. Vogler CA. Birkenmeier EH 1942 Reversal of pathology in murine mucopolysaccharidosis type VII by somatic cell gene transfer. Nature $36(2): 749-75.3$ 